\title{
Morphological organ alterations and infectious diseases in brown trout Salmo trutta and rainbow trout Oncorhynchus mykiss exposed to polluted river water
}

\author{
Heike Schmidt-Posthaus ${ }^{1, *}$, Daniel Bernet ${ }^{1}$, Thomas Wahlii ${ }^{1}$, Patricia Burkhardt-Holm ${ }^{2}$ \\ ${ }^{1}$ Centre for Fish and Wildlife Health, Institute of Animal Pathology, University of Bern, Laenggass-Strasse 122, \\ 3012 Bern, Switzerland \\ ${ }^{2}$ EAWAG (Swiss Federal Institute for Environmental Science and Technology), Überlandstrasse 133, \\ 8600 Dübendorf, Switzerland
}

\begin{abstract}
Poor water quality is discussed as a major factor causing a decline of brown trout populations in Swiss rivers. For our study we have chosen a river in the Swiss midlands, where the brown trout population has decreased dramatically during the last $10 \mathrm{yr}$ and where feral fish have shown distinctive pathological alterations. The objective of our study was to investigate whether river water may be responsible for impaired fish health leading to an increased mortality in the river. In an active monitoring program, groups of brown and rainbow trout were exposed to polluted river water for 24 mo. Fish held in tap water served as a reference. Mortality, macroscopic and histopathologic changes, and infectious agents were investigated. Compared with the reference group, high mortality rates and severe pathological alterations of the inner organs were observed in fish held in river water. Especially gills, liver and kidney of these fish showed significantly higher changes than fish from tap water. These changes were dominated by degenerative and inflammatory reactions. Additionally, several infectious agents were diagnosed in fish exposed to river water. The most important findings were furunculosis and proliferative kidney disease. Brown trout seemed to be more sensitive than rainbow trout to environmental stress and infectious agents.
\end{abstract}

KEY WORDS: River water $\cdot$ Brown trout $\cdot$ Rainbow trout $\cdot$ Mortality $\cdot$ Infectious agents $\cdot$ Morphological changes

Resale or republication not permitted without written consent of the publisher

\section{INTRODUCTION}

Declining brown trout populations have become a severe problem in many Swiss rivers over the past few decades (Frick et al. 1998, BUWAL 1999). The reasons for this decline are unclear. Water pollution and sewage plant inflows are discussed as possible contributors (Escher et al. 1999, Schmidt et al. 1999, Bernet et al. 2000). The river Langeten in the Swiss midlands is a typical example of a river in which brown trout populations have decreased over the past years (Fishing

\footnotetext{
*E-mail: heike.schmidt@itpa.unibe.ch
}

statistics 1990-1998, unpubl. data). Especially during the summer months, dead or weak brown trout could be seen downstream of sewage plants. Therefore, this river was chosen to evaluate the influence of the water quality on fish health. In a first study we examined the effect of treated waste water from 1 of the 3 sewage plants located along this river on the health status of brown and rainbow trout. Changes found in these trout were compared with alterations present in wild fish (Schmidt et al. 1999). Trout exposed to sewage effluents diluted with tap water showed only mild alterations in the inner organs, particularly degenerative liver changes (Schmidt et al. 1999). These results did not correspond to the findings in wild brown trout. In

(C) Inter-Research 2001 
wild fish, degenerative changes of liver and kidney were significantly higher downstream of sewage plant inflows. Further degenerative and proliferative changes in the gills were reported (Schmidt et al. 1999). In wild fish, proliferative kidney disease (PKD) associated with granulomatous reactions in kidney and liver was found. From these findings it was concluded that the decline of brown trout populations in the Langeten and the changes in wild fish could not be explained exclusively by the sewage effluents. Differences between the sewage-exposed trout and wild trout can be caused by stressors in the river system, e.g. abiotic parameters such as substrata, river morphology or habitat destruction, biotic parameters such as competitors and predators (Eklöv et al. 1999), or additional factors in the river water such as infections or other contaminants. A few years ago highly increased concentrations of the insecticide permethrin were found in the river downstream of a sewage plant (Ochsenbein 1997). After technical changes were made in the factory applying permethrin, the concentrations in the river decreased significantly; however, concentrations up to $40 \mu \mathrm{g} \mathrm{kg}^{-1}$ at the location of our experiment were still present in the river sediment (Water and Soil Protection Laboratory of the district of Bern [GBL] unpubl. data). At 1 sewage plant (Lotzwil), in 2 out of 4 sampling dates of pooled weekly samples of treated water effluents, the concentrations of all organic pesticides were above $20 \mu \mathrm{g} \mathrm{l}^{-1}$. For example, the following maximal concentrations were detected: atrazine $20 \mathrm{mg} \mathrm{l}^{-1}$, isoproturon $37 \mathrm{\mu g} \mathrm{l}^{-1}$, ethofumesate $1.15 \mu \mathrm{g} \mathrm{l}^{-1}$, diazinon $0.8 \mu \mathrm{g} \mathrm{l}^{-1}$, metalaxyl $0.6 \mu \mathrm{g} \mathrm{l}^{-1}$, diethyltoluamide $0.7 \mu \mathrm{g} \mathrm{l}^{-1}$ and simazine $0.6 \mu \mathrm{g} \mathrm{l}^{-1}$. In addition, nonylphenol and nonylphenol-ethoxylates were in the range of 1.6 to $4 \mu \mathrm{g} \mathrm{l}^{-1}$, galaxolides 0.1 to $0.3 \mathrm{\mu g} \mathrm{l}^{-1}$ and anionic tensides 0.1 to $0.7 \mathrm{mg} \mathrm{l}^{-1}$ (Gerecke et al. 2001, U. Ochsenbein pers. comm.).

The question arose as to which factors are responsible for or contribute to the changes found in wild fish in the Langeten. Since infections and contaminants can cause organ alterations (Bucke 1993, 1997) and these alterations may cause death and, subsequently, population declines, emphasis was put on this hypothesis. The mode of action of environmental contaminants is either direct chemical or physical damage to cell membranes or tissues (e.g. Mallat 1985, Myers et al. 1992, 1994, Johnson et al. 1993), modification of physiological and biochemical reactions (e.g. Svobodova et al. 1994, Bucheli \& Fent 1995), increased infection pressure by facultative pathogens (e.g. Khan \& Thulin 1991, Koskivaara et al. 1991, Bernet et al. 2001) or reduced resistance to infection (e.g. Sindermann 1979, Aaltonen et al. 1997, Arkoosh et al. 1998).

Thus, the aim of our study was to identify possible causes of the observed alterations in fish from the river. Therefore, the following questions were posed: (1) Could the observed changes of the health status be responsible for the fish decline? (2) Do seasonal differences occur that may be correlated to parasitic infestation pattern and that would allow a correlation between parasitic infestation and impaired health status? (3) Do differences between river water-exposed and sewage water-exposed trout, or differences between river water-exposed and wild trout occur that may give further hints on the causes of impaired health status and fish decline? (4) Are there species-specific differences between brown and rainbow trout?

This last question is of interest because a recent debate in Switzerland dealt with a possible higher resistance of rainbow trout to environmental impact, an argument for stocking rivers with this non-native species. On the other hand, rainbow trout is assumed to compete effectively with brown trout. At present the release of rainbow trout into Swiss river systems is forbidden (GSchG 1991).

\section{MATERIALS AND METHODS}

The experiments were carried out over a period of 24 mo (May 1996 through April 1998). The river examined (Langeten) is situated in the western midlands of Switzerland. Although brown trout are stocked in the Langeten every year, electrofishing revealed decreasing numbers of fish along the course of the river (Fishing statistics 1990-1998, Inspectorate of Fisheries of Bern unpubl. data), particularly below the last of 3 sewage treatment plant discharges situated along the river. According to physicochemical and biological (saprobial- and algae-index system) examinations, the river is classified as moderately to critically polluted (AquaPlus 1994, VOKOS 1997). At the location of the experiment, the Langeten receives treated sewage effluents from 3 sewage plants and several agricultural areas. River water values measured during the experiment were water temperature, $\mathrm{pH}$, oxygen concentration, dissolved organic carbon, biological oxygen demand, ammonia, nitrite, nitrate, total nitrogen, chloride, orthophosphate, total phosphorus, silicate, sulfate, sodium and potassium. Only values of ammonia occasionally exceeded the quality aims for running water in the winter months (GSchV 1998, GBL unpubl. data). For active monitoring, several trials of 60 brown trout (13 to $17 \mathrm{~cm}, 20$ to $50 \mathrm{~g}$ ) and 60 rainbow trout (19 to $22 \mathrm{~cm}, 70$ to $110 \mathrm{~g}$ ) from the stock culture at the Centre for Fish and Wildlife Health, University of Bern, Switzerland, were randomly assigned to groups and transferred to a $2000 \mathrm{l}$ fibreglass tank. This tank was located at an area near the river Langeten (river water group) and supplied with river water by means of an 
open bypass. The different species, brown and rainbow trout, were separated by a perforated steel sheet (perforation diameter $1 \mathrm{~cm}$ ). Water temperature ranged from 2 to $16^{\circ} \mathrm{C}$ over $1 \mathrm{yr}$ (GBL unpubl. data). Oxygen concentration was $\geq 8 \mathrm{mg} \mathrm{l}^{-1}$ during the study period. The reference brown trout and rainbow trout were held in tap water at the Centre for Fish and Wildlife Health in analogous tanks (200 trout per tank) with a constant flowthrough (20 $\left.1 \mathrm{~min}^{-1}\right)$ of commercial tap water (reference group). Water temperature ranged from 13 to $17^{\circ} \mathrm{C}$ and oxygen concentration was $\geq 8 \mathrm{mg} \mathrm{l}^{-1}$. All fish were fed commercial trout pellets (HOKOVIT, Bützberg, Switzerland) with a daily food ration equal to 1 to $2 \%$ of body weight. The mortality rate was recorded daily.

Fish in river water were first sampled in July 1996, after which time fish were routinely collected every 3 mo. Five brown trout and 5 rainbow trout were collected at each sampling. Additional samplings with at least 3 fish were carried out in cases of high mortalities. Fish had to be replaced several times (Table 1); however, this does not imply replication of the trials. Reference fish were collected every 6 mo. Fish were killed in buffered 3-aminobenzoic acid ethyl ester (Argent Chemical Laboratories, Redmont, USA). Immediately after death, blood was collected from the caudal vein. After centrifugation $\left(3600 \times g\right.$ for $10 \mathrm{~min}$ at $\left.4^{\circ} \mathrm{C}\right)$ the serum was stored at $-80^{\circ} \mathrm{C}$ until further investigation (up to $3 \mathrm{mo}$ ). Antibodies against the virus of the viral hemorrhagic septicemia were measured according to Meier \& Wahli (1988). Trout were weighed and measured individually. A standard necropsy was performed. Virologic, bacteriologic and parasitologic examinations were performed as described by Schmidt et al. (1999). Pieces of skin (excised cranial of the dorsal fin), gills, liver and kidney from all animals were fixed in Bouin fixative for $24 \mathrm{~h}$, routinely processed for histology and stained with hematoxylin and eosin, periodic acid-Schiff, and, if indicated, van Gieson stains. Histopathologic changes were described quali- tatively and alterations were quantitively evaluated according to an assessment tool (Bernet et al. 1999). According to the degree and extent of lesions, an organ index for each organ was determined. The sum of these organ indexes resulted in a total index for the individual fish (Tot_I). Parasites in the inner organs were examined by histology; 2 to 3 different histologic sections were investigated. To distinguish Sphaerospora sp. from sporogonic stages of PKX cells, a histochemical staining procedure using biotinylated GS-1 lectin (Griffonia simplicifolia agglutinin-1) as described by Marin de Mateo et al. (1993) was performed. PKX cells were recently identified as myxosporean belonging to Tetracapsula n. sp. (Canning et al. 1999, Saulnier et al. 1999, Kent et al. 2000).

Fish that were found dead in the tanks were, if possible, examined for infectious agents and macroscopic changes as described above.

The data of the histopathologic evaluation were checked for normal distribution using Lilliefors test and normal probability plot. Differences between nonnormally distributed data were tested using the MannWhitney $U$-test. For histopathologic alterations, relative risk (RR) values were calculated by dividing the prevalence of changes of the exposed brown trout and rainbow trout, respectively, by the respective prevalence of the reference brown and rainbow trout. These were tested using $\chi^{2}$-test according to Pearson, Mantel and Haenszel (Sachs 1997). Differences in parasite prevalence and differences in the abundance of sacciform cells in the skin between the river water and reference groups and between the brown and rainbow trout were tested using $\chi^{2}$-test. Relations between the season or the exposure time and the histopathologic changes or the prevalence of parasites were determined using Spearman's test of correlation. The level of significance of all statistical tests was set at $5 \%$ with Bonferroni-adjustments. All statistical analyses were calculated using the SYSTAT program (v8.0, SPSS Inc., Chicago, USA).

Table 1. Stocking and samplings of river water-exposed brown and rainbow trout. Number of introduced fish and exposure time in months at sampling are given. Numbers of fish sampled are shown in parentheses. -: no fish left because of high mortality rate

\begin{tabular}{|c|c|c|c|c|c|c|}
\hline \multirow{3}{*}{ No. of fish expose } & \multirow{2}{*}{$\begin{array}{c}\text { 1st trial } \\
\text { May-Aug } 1996\end{array}$} & \multirow{2}{*}{$\begin{array}{l}\text { Bro } \\
\text { 2nd trial } \\
\text { Sep-Nov } 1996\end{array}$} & \multirow{2}{*}{$\begin{array}{l}\text { Nn trout } \\
\text { 3rd trial } \\
\text { Dec 1996-Jul } 1997\end{array}$} & \multirow{3}{*}{$\begin{array}{c}\text { 4th trial } \\
\text { Nov 1997-Apr } 1998 \\
60\end{array}$} & \multirow{2}{*}{\multicolumn{2}{|c|}{$\begin{array}{cc} & \text { Rainbow trout } \\
\text { 1st trial } & \text { 2nd trial } \\
\text { May-Nov 1996 } & \text { Dec 1996-Apr } 1998\end{array}$}} \\
\hline & & & & & & \\
\hline & osed: 60 & 60 & 60 & & 60 & 60 \\
\hline \multicolumn{7}{|c|}{ Exposure time at sampling in months } \\
\hline 1st sampling & $2(5)$ & $2(5)$ & $2(6)$ & $3(5)$ & $2(5)$ & $2(5)$ \\
\hline 2nd sampling & $3(3)$ & $3(4)$ & $5(5)$ & $6(5)$ & $3(3)$ & $5(5)$ \\
\hline 3rd sampling & - & - & $8(5)$ & - & $5(5)$ & $8(5)$ \\
\hline 4th sampling & - & - & - & - & $6(3)$ & $11(5)$ \\
\hline 5th sampling & - & - & - & - & - & $14(5)$ \\
\hline 6th sampling & - & - & - & - & - & $17(5)$ \\
\hline
\end{tabular}


Table 2. Values (median) of the histological total index for the individual fish (Tot_I), circulatory, degenerative, proliferative and inflammatory index, and gill, skin, liver and kidney index of brown and rainbow trout; quartiles are shown in parentheses $(25 \% / 75 \%)$; the percentage increase of indexes of exposed fish compared with indexes of reference fish of the same species are given. *Significant differences of indexes of the river water group compared with the reference group (Mann-Whitney $U$-test; $\mathrm{p}<0.05$ )

\begin{tabular}{|c|c|c|c|c|}
\hline \multirow[t]{2}{*}{ Index } & \multicolumn{2}{|c|}{ Brown trout } & \multicolumn{2}{|c|}{ Rainbow trout } \\
\hline & $\begin{array}{l}\text { Reference } \\
(\mathrm{n}=23)\end{array}$ & $\begin{array}{l}\text { River water } \\
\quad(\mathrm{n}=43)\end{array}$ & $\begin{array}{l}\text { Reference } \\
\quad(\mathrm{n}=20)\end{array}$ & $\begin{array}{l}\text { River water } \\
\quad(\mathrm{n}=46)\end{array}$ \\
\hline $\begin{array}{l}\text { Total index } \\
\text { (Tot_I) }\end{array}$ & $20(17 / 21.5)$ & $\begin{array}{c}29(19 / 47)^{*} \\
45 \%\end{array}$ & $17(13.75 / 18)$ & $\begin{array}{c}26.5(22 / 35)^{*} \\
56 \%\end{array}$ \\
\hline $\begin{array}{l}\text { Circulatory } \\
\text { index }\end{array}$ & $0(0 / 1)$ & $\begin{array}{c}0(0 / 0) \\
0 \%\end{array}$ & $0(0 / 1)$ & $\begin{array}{c}0(0 / 0) \\
0 \%\end{array}$ \\
\hline $\begin{array}{l}\text { Degenerative } \\
\text { index }\end{array}$ & $9(7 / 12)$ & $\begin{array}{c}13(10.5 / 22)^{*} \\
44 \%\end{array}$ & $10(8 / 11.25)$ & $\begin{array}{c}14(11 / 19)^{*} \\
40 \%\end{array}$ \\
\hline $\begin{array}{l}\text { Proliferative } \\
\text { index }\end{array}$ & $6(4 / 6.5)$ & $\begin{array}{c}8(6 / 16)^{*} \\
33 \%\end{array}$ & $4(2 / 5)$ & $\begin{array}{c}8(6 / 10)^{*} \\
100 \%\end{array}$ \\
\hline $\begin{array}{l}\text { Inflammatory } \\
\text { index }\end{array}$ & $2(0 / 3.5)$ & $\begin{array}{l}6(4 / 10)^{*} \\
200 \%\end{array}$ & $2(0 / 3.25)$ & $\begin{array}{l}5(2 / 8)^{*} \\
150 \%\end{array}$ \\
\hline Gill index & $9(6.5 / 10)$ & $\begin{array}{c}11(8.5 / 13) \\
22 \%\end{array}$ & $5(4 / 625)$ & $\begin{array}{c}10(8 / 11.75)^{*} \\
100 \%\end{array}$ \\
\hline Skin index & $1(0 / 2)$ & $\begin{array}{l}2(1 / 3) \\
100 \%\end{array}$ & $1(0 / 2.25)$ & $\begin{array}{l}3(2 / 4)^{*} \\
200 \%\end{array}$ \\
\hline Liver index & $3(1 / 4.5)$ & $\begin{array}{c}9(5 / 15.5)^{*} \\
200 \%\end{array}$ & $4(2 / 6)$ & $\begin{array}{c}5(2.25 / 9) \\
25 \%\end{array}$ \\
\hline Kidney index & $5(3 / 7)$ & $\begin{array}{c}7(4 / 17.5) \\
40 \%\end{array}$ & $5(4 / 7)$ & $\begin{array}{c}9(6 / 13)^{*} \\
80 \%\end{array}$ \\
\hline
\end{tabular}

\section{RESULTS}

\section{Mortality}

No mortality occurred in the reference fish held in tap water. In contrast, high mortality rates occurred in fish exposed to river water (Fig. 1); the rate was clearly higher in brown trout than in rainbow trout (Fig. 1). Especially in the summer months (July to October) the mortality rate was elevated. Mortality rates also differed between years: the highest rates were seen in 1996.

\section{Macroscopic findings}

In the reference animals no macroscopic changes were found.

Brown and rainbow trout held in river water showed mild ulceration of the upper and lower jaw and several fish showed skin erosions and ulcers.

In the inner organs, changes in the spleen, liver and kidney were most obvious. Especially in July and August splenomegaly, proliferative nephritis and multiple areas of necrosis in the liver were diagnosed macroscopically. In the other months these changes occurred only occasionally.

\section{Histologic findings}

Brown trout

According to the Tot_I, brown trout held in river water showed significantly more severe histopathologic alterations than reference fish (Mann-Whitney $U$-test, $U=$ 271.5; p = 0.003) (Table 2). Components of the Tot_I are circulatory changes, degenerative changes, proliferative changes, inflammatory changes and neoplasms. Degenerative changes (Mann-Whitney $U$ test, $U=288$; $\mathrm{p}=0.005)$, proliferative changes (Mann-Whitney $U$-test, $U=275$; $\mathrm{p}=0.003)$ and inflammatory changes (Mann-Whitney $U$-test, $U=166.5 ; \mathrm{p}<$ 0.001 ) differed significantly between the reference and exposed groups. Indexes of all 4 organs (gill, skin, liver and kidney) were elevated in the exposed group; however, significant differences were seen only in liver values (Mann-Whitney $U$-test, $U=$ 133.5; $\mathrm{p}<0.001$ ).

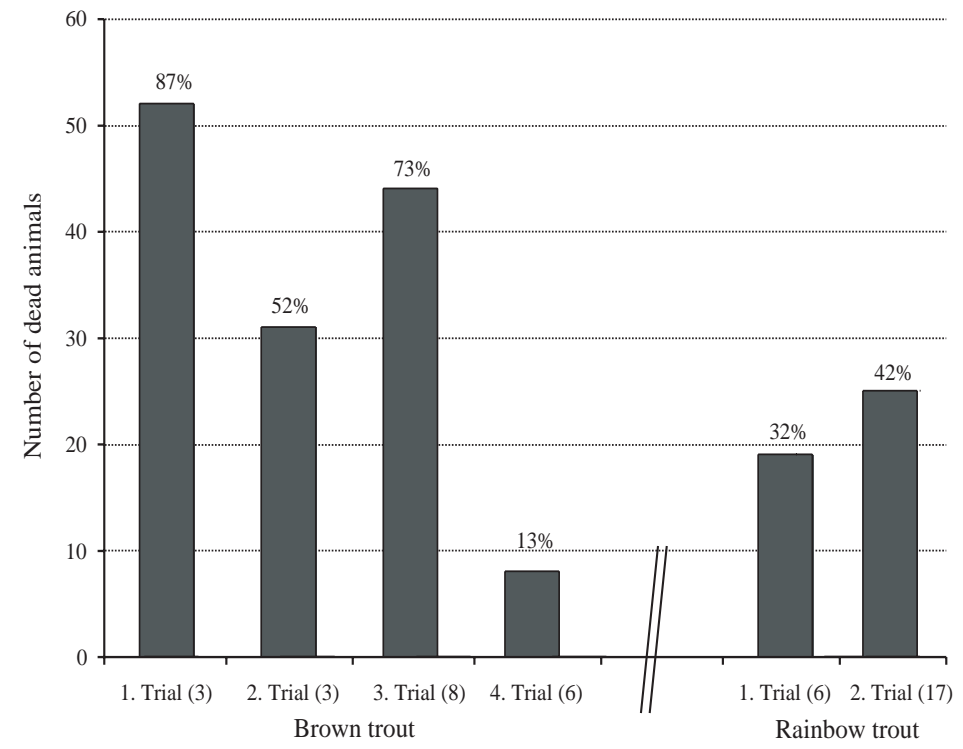

Fig. 1. Mortality rate of river water-exposed brown and rainbow trout. Mortality was calculated at the end of every trial. Percentage of mortality per trial is given. Exposure time in months shown in parentheses 
There was no significant correlation between exposure time and the Tot_I values or the organ indexes of the brown trout held in river water (Spearman correlation, $\mathrm{n}=43$; $\mathrm{p}>0.05$ ). There was, however, a significant correlation between the season and the Tot_I values (Spearman correlation, $\mathrm{r}_{\mathrm{s}}=0.709 ; \mathrm{p}<0.001$ ) and the organ indexes (Spearman correlation, $\mathrm{n}=43$, $\mathrm{r}_{\mathrm{s} \text { gill }}=0.573, \mathrm{r}_{\mathrm{s} \text { skin }}=0.362, \mathrm{r}_{\mathrm{s} \text { liver }}=0.576, \mathrm{r}_{\mathrm{s} \text { kidney }}=$ 0.673 ; $\mathrm{p}<0.05)$.

Gills. Plasma alterations, such as granulated eosinophilic cytoplasm or vacuolation, epithelial cell lifting and hyperplasia of the epithelial cells, were more prevalent and more pronounced in the river water group than in the reference group. Multifocal necrosis of the gill epithelial cells occurred only in the river water group. Compared with the reference fish, the river water-exposed trout showed a significantly higher RR for epithelial cell lifting $\left(\mathrm{RR}=1.8 ; \chi^{2}=6.7\right.$; $\mathrm{p}<0.01)$, hyperplasia $\left(\mathrm{RR}=1.2 ; \chi^{2}=6.7 ; \mathrm{p}<0.01\right)$ and necrosis of epithelial cells $\left(\mathrm{RR}={ }^{*}\right.$ [cannot be evaluated because the reference value is 0$]_{i} \chi^{2}=14.1 ; \mathrm{p}<0.001$ ).

Epitheliocystis caused by a chlamydia was diagnosed only in the river water-exposed brown trout. These epitheliocystis cysts showed no surrounding inflammatory reaction.

Skin. Brown trout exposed to river water showed a higher prevalence and abundance of multifocal skin erosions and ulcers than reference fish. Most of these alterations were accompanied by a mild, mainly lymphocytic infiltration of the surrounding tissue. The number of sacciform cells in the epidermis was significantly increased in the river water group $\left(\chi^{2}=4.9 ; \mathrm{p}<\right.$ 0.05). Further structural alterations included irregular structure of the basal cell layer.

Liver. Compared with the reference brown trout, the river water group showed an increased prevalence and severity of structural alterations, such as distended sinusoids and separation of the liver cells, of plasma alterations, such as condensed eosinophilic or granulated cytoplasm, and of pericholangiar and perivascular fibrosis and lymphohistiocytic infiltration. Increased numbers of necrotic single cells and small foci of necrosis were diagnosed in $35 \%$ of the river waterexposed brown trout. In $14 \%$ of the trout held in river water, Tetracapsula n. sp., surrounded by a granulomatous infiltration, were found in the parenchyma. Brown trout of the river water group had a significantly increased $\mathrm{RR}$ of structural alterations $\left(\mathrm{RR}=3.2 ; \chi^{2}=\right.$ 8.9; $\mathrm{p}<0.01)$, necrosis of the hepatocytes $\left(\mathrm{RR}={ }^{*} ; \chi^{2}=\right.$ $10.2 ; \mathrm{p}<0.01$ ), and infiltration with lymphocytes and single macrophages either around bile ducts and vessels or randomly distributed in the parenchyma (RR $\left.=2.4 ; \chi^{2}=25.4 ; \mathrm{p}<0.001\right)$.

Kidney. Brown trout exposed to river water showed a higher prevalence and severity of tubulonephrosis, deposits of desquamating tubular cells, hyalinous casts in the tubules and peritubular fibroblast proliferation. However, this increase was not significant $\left(\chi^{2}\right.$-test, $\mathrm{p}>$ 0.05). Mild multifocal necrosis of interstitial cells occurred in $14 \%$ of the river water-exposed brown trout. Infection with Tetracapsula n. sp. was diagnosed in $35 \%$ of animals of the river water group. The extrasporogonic stages were associated with mild to severe proliferation of the interstitial tissue and granulomatous infiltration. Sporogonic stages in the tubules were not associated with an inflammatory reaction. Infection with Sphaerospora sp. in the tubules was also diagnosed only in the river water-exposed trout. Infection with these parasites was associated with only mild degenerative tubular changes in severe infestations.

\section{Rainbow trout}

Reference rainbow trout showed significantly lower Tot_I values than the river water group (Mann-Whitney $U$-test; $U=87.0 ; \mathrm{p}<0.001)$. According to the pattern of the changes, values of degenerative, proliferative and inflammatory alterations differed significantly (Mann-Whitney $U$-test; $U=189.5$ [degenerative], $U=$ 151.0 [proliferative], $U=208.0$ [inflammatory]; $\mathrm{p}<$ 0.001). Gill, skin and kidney values of reference fish were significantly lower than those of exposed fish (Mann-Whitney $U$-test; $U=46.5$ [gill]), $U=224.0$ [skin], $U=198.5$ [kidney]; $\mathrm{p} \leq 0.001$ ).

The lesions found in rainbow trout corresponded qualitatively to those found in brown trout. Rainbow trout of the river water group showed a significantly higher RR of plasma alterations of gill epithelial cells $\left(\mathrm{RR}=3.3 ; \chi^{2}=11.2, \mathrm{p}<0.001\right)$, hypertrophy of gill epithelial cells $\left(\mathrm{RR}=1.6, \chi^{2}=11.1, \mathrm{p}<0.001\right)$ and structural alterations of the skin $\left(\mathrm{RR}=1.4, \chi^{2}=11.2 ; \mathrm{p}<\right.$ 0.001 ), such as erosions, than reference fish. Similar to brown trout, only the river water-exposed rainbow trout were infected with Tetracapsula n.sp. (prevalence $26 \%$ ), resulting in a higher RR to show structural alterations $\left(\mathrm{RR}={ }^{*}{ }^{*} \chi^{2}=7.6, \mathrm{p}<0.01\right)$ and infiltration of the kidney interstitium ( $\left.\mathrm{RR}={ }^{*}, \chi^{2}=12.3, \mathrm{p}<0.001\right)$. In $7 \%$ of the river water-exposed rainbow trout Tetracapsula n.sp. were also found in the liver parenchyma.

In the rainbow trout held in river water the season had a significant influence only on the development of kidney alterations (Spearman correlation, $\mathrm{r}_{\mathrm{s}}=0.338$; $\mathrm{p}<0.05)$.

\section{Infectious diseases}

Virologic infections

No viruses were isolated. 
Table 3. Prevalence (Prev, \%) and abundance (Abun) of parasites found in river water-exposed and reference brown and rainbow trout. ${ }^{a}$ Significant seasonal differences $\left(\chi^{2}\right.$ test; $\left.\mathrm{p}<0.05\right)$; ${ }^{\mathrm{b}}$ Significant differences to the reference $\left(\chi^{2}\right.$ test; $\left.\mathrm{p}<0.05\right)$; ${ }^{\mathrm{s}}$ significant species differences $\left(\chi^{2}\right.$ test; $\left.\mathrm{p}<0.05\right)$

\begin{tabular}{|c|c|c|c|c|c|c|c|c|c|}
\hline \multirow{3}{*}{ Parasite } & \multirow[t]{3}{*}{ Location } & \multicolumn{4}{|c|}{- Brown trout } & \multicolumn{4}{|c|}{ Rainbow trout } \\
\hline & & \multicolumn{2}{|c|}{ Reference $(n=23)$} & \multicolumn{2}{|c|}{ River water $(n=43)$} & \multicolumn{2}{|c|}{ Reference $(n=20)$} & \multicolumn{2}{|c|}{ River water $(n=46)$} \\
\hline & & Prev & Abun & Prev & Abun & Prev & Abun & Prev & Abun \\
\hline \multicolumn{10}{|c|}{ Ciliophora/Oligohymenophorea } \\
\hline Sessile peritrichia & Skin & 0 & 0 & $60^{\mathrm{c}}$ & 1.0 & 0 & 0 & 11 & 0.6 \\
\hline Trichodina sp. & Skin & 0 & 0 & 40 & 1.0 & 5 & 3.0 & $48^{\mathrm{b}}$ & 2.0 \\
\hline Ichthyophthirius multifiliis & Skin & 0 & 0 & 2 & 0.5 & 0 & 0 & 2 & 0.5 \\
\hline \multicolumn{10}{|l|}{ Myxozoa } \\
\hline Tetracapsula n. sp. & Kidney & 0 & 0 & $35^{\mathrm{a}}$ & 0.9 & 0 & 0 & $26^{\mathrm{a}}$ & 1.0 \\
\hline Sphaerospora sp. & Kidney & 0 & 0 & $37^{\mathrm{a}, \mathrm{c}}$ & 0.9 & 0 & 0 & 0 & 0 \\
\hline \multicolumn{10}{|l|}{ Plathelminthes/Monogenea } \\
\hline Gyrodactylus sp. & Skin & 17 & 0.6 & $44^{\mathrm{a}, \mathrm{b}}$ & 1.2 & 20 & 0.6 & 35 & 1.4 \\
\hline
\end{tabular}

\section{Bacteriologic findings}

In the reference fish no bacteria were isolated. During the regular samplings 1 river water-exposed brown trout and 1 rainbow trout showed a systemic infection with Aeromonas salmonicida. But animals that were found dead between the samplings and that could still be examined bacteriologically showed a prevalence of furunculosis (infection with A. salmonicida) of approximately $50 \%$.

Of the river water-exposed brown trout $21 \%$ showed an infection of the gills with epitheliocystis. Epitheliocystis infections did not occur in the other groups.

\section{Parasitologic findings}

Brown trout. In the reference fish no infestations with parasites were found except a low number of Gyrodactylus sp. in 4 animals. In contrast, $93 \%$ of the river water-exposed brown trout showed a parasitic infestation. The prevalence of fish infested with Gyrodactylus sp. also increased significantly over time in the river water-exposed fish $\left(\chi_{1,1}^{2}=4.74, p=0.03\right)$. On average the brown trout held in river water were infested with 2.2 parasite species per fish. The whole parasite fauna in the exposed brown trout consisted of 6 species: 4 species on the skin (Gyrodactylus sp., sessile peritrichia, Trichodina sp., Ichthyophthirius multifiliis) and 2 species in the kidney (Tetracapsula n. sp., Sphaerospora sp.). The prevalence and abundance of these parasites in the different groups are shown in Table 3. Significant seasonal differences were found. Gyrodactylus sp. was significantly more frequent in autumn $\left(\chi_{3,1}^{2}=10.0 ; \mathrm{p}=0.02\right)$, Tetracapsula n. sp. in summer $\left(\chi_{3,1}^{2}=22.7 ; \mathrm{p}<0.001\right)$, and Sphaerospora $\mathrm{sp}$. in spring and summer $\left(\chi_{3,1}^{2}=18.5, \mathrm{p}<0.001\right)$.
Rainbow trout. Skin of reference rainbow trout was slightly infested with Gyrodactylus sp. and Trichodina sp. Of the rainbow trout held in river water $76 \%$ showed a parasitic infestation. Compared with the reference fish, in the river water group the prevalence of Trichodina sp. infestations was significantly higher $\left(\chi_{1.1}^{2}=10.37 ; \mathrm{p}=0.001\right)$ and the abundance was clearly elevated. On average river water-exposed trout were parasitized with 1 parasite species per fish. The whole parasite fauna of the river water-exposed rainbow trout consisted of 4 parasite species on the skin (Gyrodactylus sp., sessile peritrichia, Trichodina sp., Ichthyophthirius multifiliis) and Tetracapsula n. sp. in the kidney (Table 3). Only Tetracapsula n. sp. were significantly more frequent during the summer months $\left(\chi_{3,1}^{2}=41.2 ; \mathrm{p}<0.001\right)$. Compared with brown trout, rainbow trout exposed to river water showed significantly lower prevalences in parasitic infestation with sessile peritrichia and Sphaerospora sp. $\left(\chi_{1,1}^{2}=24.08\right.$, $\left.\mathrm{p}<0.001 ; \chi_{1,1}^{2}=20.87, \mathrm{p}<0.001\right)$.

\section{DISCUSSION}

The aim of the present study was to investigate the impact of water quality (river water compared with tap water) on the health status of trout in order to find possible explanations for the decline of brown trout populations. River water-exposed brown trout showed high mortality rates whereas in the reference fish no mortality occurred. Histopathological changes in the gills, liver and kidney, which may result in decreased vitality, were found in the river water group. Additionally, several exposed animals showed high infestation rates with primary and secondary pathogenic parasites. These findings indicate impaired fish health in river water-exposed animals. The pattern of histopathologic 
changes in our study as well as the infestation rates with parasites were comparable with changes found in wild fish in the lower part of the river (Schmidt et al. 1999). Several histopathologic alterations correlated with infectious agents, e.g. granulomatous nephritis with PKD infection (Clifton-Hadley et al. 1987, Hoffmann \& El-Matbouli 1994). Other lesions, such as pericholangiar and perivascular fibrosis, lymphocytic infiltration in the liver parenchyma and multifocal necrosis, could not clearly be assigned to a specific cause. These changes may either be part of a PKD infection or be directly induced by water ingredients as they were present in fish without PKD infection too. Lesions described here are also found in fish exposed to organic contaminants (Myers et al. 1992, Johnson et al. 1993) or to pesticides (Hinton et al. 1993, BurkhardtHolm et al. 1998). In the gills no infectious agent causing lesions was isolated. The described changes, such as epithelial cell lifting, multifocal necrosis and epithelial hyperplasia, are not specific to one particular agent and can be induced by a range of different stressors including pesticides, heavy metals and low oxygen content (reviewed in Mallat 1985, Haya 1989). Comparable lesions were also described following exposure to wastewater (Carline et al. 1987). Low concentrations of permethrin up to $40 \mu \mathrm{g} \mathrm{kg}^{-1}$ at the location of our experiment were still present in the river sediment (GBL unpubl. data). Therefore, release of low amounts and chronic effects on the fish health might be possible. Whereas rupture and necrosis of epithelial cells are believed to be a direct effect of irritants, epithelial hyperplasia is interpreted as a defence response of fish (reviewed in Mallat 1985). All together, the impaired fish health in our study may indicate a decreased vitality of wild brown trout populations in the Langeten. Pollution with sewage effluents was discussed as one possible cause. However, in a previous study we showed that sewage water effluents of 1 sewage plant on its own did not cause mortality and fish showed only mild to moderate histopathologic changes in the liver (Schmidt et al. 1999). In this former study, fish were not exposed to infectious agents normally present in a river. Thus, pathogenic parasites may be important factors for the results of the present study.

In the reference brown trout only Gyrodactylus sp., and in the reference rainbow trout additionally Trichodina sp., were found in low abundance. These parasites were probably introduced with the stock fish. As reference fish were kept in tap water, an infestation with further parasite species via the water route was not likely.

In the river water-exposed trout the parasitic infestation was mainly limited to secondary pathogenic agents, such as the skin parasites and Sphaerospora sp. in the kidney. Additionally, Tetracapsula n. sp. was diagnosed in liver and kidney. A similar parasite fauna was found in wild fish with increasing prevalence and abundance of Tetracapsula n. sp. along the course of the river (Schmidt et al. 1999). A number of infectious diseases are known to be favored by environmental stress (reviewed in Sindermann 1979, Bucke 1997). Environmental stress can promote increased parasitism in fish because of a decreased host immune response (Khan \& Thulin 1991, Poulin 1992, Nowak 1999) or direct effects on the parasite fauna (Valtonen et al. 1997). However, effects can also be dual: either pollution stress can influence the prevalence of parasites directly or indirectly, or the parasite infestation may decrease the host resistance to toxic pollutants (Sindermann 1979). Tetracapsula n. sp. was shown to be promoted by water contaminants (Hoffmann \& Dangschat 1981, Clifton-Hadley et al. 1984). This hypothesis was supported in the Langeten because prevalence of PKD in wild fish increased significantly along the course of the river (Schmidt et al. 1999). In our study, in both species a significant increase of PKD infections during the summer months was evident. As the Tetracapsula n. sp. cycle is temperature dependent, high summer temperatures have a positive influence on this parasite (Clifton-Hadley et al. 1984). Thus, the higher mortality rate in our tanks during the summer months might be caused partly by these PKD infections. Also in the river Langeten, especially during the summer months, a high mortality rate in wild immature brown trout was reported and all dead fish were found to harbor Tetracapsula n. sp. (Inspectorate of Fisheries of Bern pers. comm., and Schmidt-Posthaus et al. unpubl. data). PKD is known as a significant factor limiting salmonid production in Europe and North America (Hedrick et al. 1993) but there is little information about PKD in wild fish and its impact on wild populations (Feist \& Bucke 1993). Longshaw et al. (1999) showed that bryozoans, presumably a further host in the life cycle of Tetracapsula n. sp., occur in rivers enzootic for PKD in the UK. The same species of bryozoans also occur in Swiss rivers (Frutiger, EAWAG, pers. comm.). We conclude that special stress conditions, such as high temperature, decreased water quality, and increased prevalence and abundance of secondary infectious agents, may favor infection with PKD leading to increased mortality rates in wild brown trout populations. To further examine the significance of PKD for Swiss brown trout populations, the distribution of PKD in Swiss rivers will be investigated in a larger surveillance and compared with population data (Burkhardt-Holm 2000).

Other than PKD, only secondary pathogenic parasites were found in the river water-exposed trout. Nevertheless, there was a clear increase in Gyrodactylus sp. prevalence and abundance in both river water 
groups, brown and rainbow trout, compared with reference trout. In earlier studies we showed that Gyrodactylus sp. was favored by sewage plant effluents (Schmidt et al. 1999, Bernet et al. 2001). In river water-exposed brown trout, significant seasonal differences in Gyrodactylus sp. infestations (highest prevalence in autumn) were found. This can also result from direct influences of environmental factors, such as temperature, or a secondary increased replication rate because of a suppressed immune system of the host. It is known that temperature and oxygen content are the most important physical parameters for monogenea (Williams \& Jones 1994). Two other secondary pathogenic parasites (sessile peritrichia and Trichodina sp.) were only observed in the river water groups or were significantly increased in these fish (Trichodina sp. on the skin of rainbow trout). It has been previously shown that both parasites can be favored by environmental pollution (Roberts 1989, Khan \& Thulin 1991, Valtonen \& Koskivaara 1994, Escher et al. 1999, Bernet et al. 2001).

From our results we conclude that Tetracapsula n. sp. is the most harmful among the parasite species found in this study.

A further infectious agent that may play a role is Aeromonas salmonicida, which causes furunculosis. Furunculosis is known to cause high mortality among salmonids (Roberts 1989). This disease was diagnosed in several fish found dead in our tanks. A. salmonicida can exist in carriers or as a latent infection that can develop into a disease outbreak if the fish are stressed (Snieszko 1974, Sindermann 1979).

A further aim of our study was to compare brown trout with rainbow trout with respect to their sensitivity to environmental stress and infectious agents. Compared to rainbow trout, exposed brown trout showed a clearly higher mortality rate. Histopathologically, the pattern of distribution of the alterations differs between the 2 species. River water-exposed brown trout showed increased liver alterations, whereas in river water rainbow trout, gill and skin changes were more pronounced. This was also shown in our previous study (Schmidt et al. 1999). Therefore, it has to be considered that the exposure time was not the same because of the above-mentioned increased mortality in brown trout. Qualitatively, changes such as gill epithelial necrosis, hepatocyte necrosis and infiltration were also more pronounced in brown trout. Furthermore, there were significant differences in the prevalence of 2 facultative pathogenic parasites (sessile peritrichia and Sphaerospora sp.). There were also species-specific differences in the prevalence of PKD, although these differences were not significant. PKD was more frequent in brown trout than in rainbow trout. Our results correspond to earlier findings by Pickering et al. (1989) and Schneeberger (1995), who showed that brown trout are more sensitive to stress situations, expressed as a higher incidence of bacterial and fungal infections and higher mortality rates caused by diseases. Nevertheless, both species showed a variety of changes indicating decreased water quality, which should be improved. Such an improvement may make stocking with rainbow trout unnecessary.

In conclusion, we showed that fish were exposed to various infectious agents under field conditions. Additional environmental stress, such as high temperature and low water quality, could have favored some primary pathogenic agents, such as Tetracapsula n. sp. and Aeromonas salmonicida, which could have led to increased mortality. Further studies have to evaluate the overall importance of these infectious agents in river systems with declining fish populations and whether the higher incidence of these agents correlates with a depressed immune system of the animals.

Acknowledgements. Thanks are due to Mr Eberhardt and Mr Wälchli for taking care of the fish and recording the mortality rates; the Water and Soil Protection Laboratory of the district of Bern (GBL) for providing data of water analysis; $\mathrm{Mr}$ R. Benguerel, Dr G. Lamche, Mrs L. Lagcher and E. Oldenberg for assistance during the samplings; as well as to the laboratory of histology of the Institute of Animal Pathology. Thanks are due to Mrs U. Forster for excellent technical assistance in histochemistry. This work was supported by the Swiss Federal Agency for Environment, Forests and Landscape, the Inspectorate of Fisheries of Bern, the GBL and the Swiss National Science Foundation (3100-045894.95/1).

\section{LITERATURE CITED}

Aaltonen TM, Valtonen ET, Jokinen EI (1997) Immunoreactivity of roach, Rutilus rutilus, following laboratory exposure to bleached pulp and paper mill effluents. Ecotoxicol Environ Safety 38:266-271

AquaPlus (1994) Beurteilung der Gewässergüte in der Langete und Vergleich mit früheren Untersuchungen. Gewässerschutzamt des Kantons Bern, Bern

Arkoosh L, Casillas E, Clemons E, Kagley N, Olson R, Reno P, Stein JE (1998) Effect of pollution on fish diseases: potential impacts on salmonid populations. J Aquat Anim Health 10:182-190

Bernet D, Schmidt H, Meier W, Burkhardt-Holm P, Wahli T (1999) Histopathology in fish: proposal for a protocol to assess aquatic pollution. J Fish Dis 22:24-35

Bernet D, Schmidt H, Wahli T, Burkhardt-Holm P (2000) Effects of waste water on fish health: an integrated approach to biomarker responses in brown trout (Salmo trutta L.). J Aquat Environ Stress Recovery (in press)

Bernet D, Schmidt H, Wahli T, Burkhardt-Holm P (2001) Effects of treated domestic waste water on infectious agents in brown trout (Salmo trutta L.). Fischökologie 12:1-16

Bucheli TD, Fent K (1995) Induction of cytochrome P450 as a biomarker for environmental contamination in aquatic ecosystems. Crit Rev Environ Sci Technol 25:201-268

Bucke D (1993) Aquatic pollution effects on the health of fish and shellfish. Parasitology 106:25-37 
Bucke D (1997) Facts and myths regarding pollution and fish health. Bull Eur Assoc Fish Pathol 17:191-196

Burkhardt-Holm P (2000) Wie weiter mit den Hypothesen zum Fischnetz? Fischnetz info 5, 2000. EAWAG, Dübendorf 5:17-19

Burkhardt-Holm P, Oulmi Y, Schroeder A, Storch V, Braunbeck $\mathrm{T}$ (1998) Toxicity of 4-chloroaniline in early lifestages of zebrafish (Danio rerio): II. Cytopathology and regeneration of liver and gills after prolonged exposure to water-borne 4-chloroaniline. Arch Environ Contam Toxicol 37:85-102

BUWAL (Bundesamt für Umwelt, Wald und Landschaft) (1999) Fischrückgang in schweizerischen Fliessgewässern. Mitt Fischerei 63

Canning EU, Curry A, Feist SW, Longshaw M, Okamura B (1999) Tetracapsula bryosalmonae n. sp. for PKX organism, the cause of PKD in salmonid fish. Bull Eur Assoc Fish Pathol 19:203-206

Carline RF, Benson AJ, Rothenbacher H (1987) Long-term effects of treated domestic wastewater on brown trout. Water Res 21:1409-1415

Clifton-Hadley RS, Bucke D, Richards RH (1984) Proliferative kidney disease of salmonid fish. A review. J Fish Dis 7: 363-377

Clifton-Hadley RS, Bucke D, Richards RH (1987) A study of the sequential clinical and pathological changes during proliferative kidney disease in rainbow trout, Salmo gairdneri Richardson. J Fish Dis 10:335-352

Eklöv AG, Greenberg LA, Brönmark C, Larsson P, Berglund O (1999) Influence of water quality, habitat and species richness on brown trout populations. J Fish Biol 54:33-43

Escher M, Wahli T, Büttner S, Meier W, Burkhardt-Holm P (1999) The effect of sewage plant effluent on brown trout (Salmo trutta fario): a cage experiment. Aquat Sci 61: 93-110

Feist SW, Bucke D (1993) Proliferative kidney disease in wild salmonids. Fish Res 17:51-58

Frick E, Nowak D, Reust C, Burkhardt-Holm P (1998) Der Fischrückgang in den schweizerischen Fliessgewässern. Gas-Wasser-Abwasser 4:261-264

Gerecke A, Müller S, Sägesser M, Ochsenbein U, Popow G (2001) Pestizideinträge via Kläranlage. Gas-Wasser-Abwasser (in press)

GSchG (1991) Gewässerschutzgesetz, 1991, Bern, SR 814.20, AS 1992 1860. Council of Ministers, Switzerland

GSchV (1998) Gewässerschutzverordnung, 1998, Bern, SR 814.201, AS 1998 2863. Council of Ministers, Switzerland

Haya K (1989) Toxicity of pyrethroid insecticides to fish. Environ Toxicol Chem 8:381-391

Hedrick RP, MacConnell E, de Kinkelin P (1993) Proliferative kidney disease of salmonid fish. Annu Rev Fish Dis 3: $277-290$

Hinton DE, Baumann PC, Gardner GR, Hawkins WE, Hendricks JD, Murchelano RA, Okihiro MS (1993) Histopathologic biomarkers. In: Huggett RJ, Kimerle RA, Mehrle PMJ, Bergmann HL (eds) Biomarkers-biochemical, physiological, and histological markers of anthropogenic stress. Lewis Publishers, London, p 155-210

Hoffmann R, Dangschat H (1981) A note on the occurrence of proliferative kidney disease in Germany. Bull Eur Assoc Fish Pathol 1:33

Hoffmann RW, El-Matbouli M (1994) Proliferative kidney disease (PKD) as an important myxosporean infection in salmonid fish. In: Pike AW, Lewis JW (eds) Parasitic diseases of fish. Samara Publishing Limited, London, p 3-16

Johnson LL, Stehr CM, Olson OP, Myers MS, Pierce SM, Wigren CA, McCain BB, Varanasi U (1993) Chemical con- taminants and hepatic lesions in winter flounder (Pleuronectes americanus) from the northeast coast of the United States. Environ Sci Technol 27:2759-2771

Kent ML, Khattra J, Hedrick RP, Devlin RH (2000) Tetracapsula renicola n. sp. (Myxozoa: Saccosporidae); the PKX myxozoan - the cause of proliferative kidney disease of salmonid fishes. J Parasitol 86:103-111

Khan RA, Thulin J (1991) Influence of pollution on parasites of aquatic animals. Adv Parasitol 30:201-238

Koskivaara M, Valtonen ET, Prost M (1991) Dactylogyrids on the gills of roach in central finland: features of infection and species composition. Int J Parasitol 21:565-572

Longshaw M, Feist SW, Canning EU, Okumura B (1999) First identification of PKX in bryozoans from the United Kingdom-molecular evidence. Bull Eur Assoc Fish Pathol 19: $146-148$

Mallatt J (1985) Fish gill structural changes induced by toxicants and other irritants: a statistical review. Can J Fish Aquat Sci 42:630-648

Marin de Mateo M, Adams A, Richards RH, Castagnaro M, Hedrick RP (1993) Monoclonal antibody and lectin probes recognize developmental and sporogonic stages of PKX, the causative agent of proliferative kidney disease in European and North American salmonid fish. Dis Aquat Org 15:23-29

Meier W, Wahli T (1988) Viral haemorrhagic septicaemia (VHS) in grayling (Thymallus thymallus). J Fish Dis 11: 481-487

Myers MS, Olson OP, Johnson LL, Stehr CS, Hom T, Varanasi U (1992) Hepatic lesions other than neoplasma in subadult flatfish from Puget Sound, Washington: relationships with indices of contaminant exposure. Mar Environ Res 34: $45-51$

Myers MS, Johnson LL, Olson OP, Stehr CM, Lomax DP, Horness BH, Anulacion BF, Willis ML, Collier TK, McCain BB, Stein JE, Varanasi U (1994) Toxicopathic hepatic lesions and other biomarkers of exposure to chemical contaminants in marine bottomfish species from the northeast and pacific coasts, U.S.A. In: Bylund G, Lönnström, LG (eds) Diseases and parasites of flounder (Platichthys flesus) in the Baltic Sea. The Baltic Marine Biologists Publication, Turku/Abo, p 81-98

Nowak BF (1999) Significance of environmental factors in aetiology of skin diseases of teleost fish. Bull Eur Assoc Fish Pathol 19:290-292

Ochsenbein U (1997) Schleichendes Fischsterben in bernischen Mittellandgewässern. Informationsbulletin. Bau-, Verkehrs- und Energiedirektion des Kantons Bern, Bern, p 2-6

Pickering AD, Pottinger TG, Carragher JF (1989) Differences in the sensitivity of brown trout, Salmo trutta L., and rainbow trout, Salmo gairdneri Richardson, to physiological doses in cortisol. J Fish Biol 34:757-768

Poulin R (1992) Toxic pollution and parasitism in freshwater fish. Parasitol Today 8:58-61

Roberts RJ (1989) Fish pathology. Baillière Tindall, London

Sachs L (1997) Angewandte Statistik. Springer-Verlag, Berlin

Saulnier D, Philippe H, de Kinkelin P (1999) Molecular evidence that the proliferative kidney disease organism unknown (PKX) is a myxosporean. Dis Aquat Org 36:209-212

Schmidt H, Bernet D, Wahli T, Meier W, Burkhardt-Holm P (1999) Active biomonitoring with brown trout and rainbow trout in diluted sewage plant effluents. J Fish Biol 54: 585-596

Schneeberger U (1995) Abklärungen zum Gesundheitszustand von Regenbogenforelle (Oncorhynchus mykiss), Bachforelle (Salmo trutta fario) und Groppe (Cottus gobio) im 
Liechtensteiner-, Werdenberger- und Rheintaler-Binnenkanal. Inaugural dissertation, Universität Bern

Sindermann CJ (1979) Pollution-associated diseases and abnormalities of fish and shellfish: a review. Fish Bull 76: 717-749

Snieszko SF (1974) The effects of environmental stress on outbreaks of infectious diseases of fish. J Fish Biol 6:197-208

Svobodova Z, Vykusova B, Machova J (1994) The effects of pollutants on the selected haematological and biochemical parameters in fish. In: Müller R, Lloyd R (eds) Sublethal and chronic effects of pollutants on freshwater fish. Fishing News Books, Oxford, p 39-52

Editorial responsibility: Thomas Braunbeck, Heidelberg, Germany
Valtonen ET, Koskivaara M (1994) Relationships between the parasites of some wild and cultured fishes in two lakes and a fish farm in central Finland. Int J Parasitol 24:109-118

Valtonen ET, Holmes JC, Koskivaara M (1997) Eutrophication, pollution, and fragmentation: effects on parasite communities in roach (Rutilus rutilus) and perch (Perca fluviatilis) in four lakes in central Finland. Can J Fish Aquat Sci 54:572-585

VOKOS (1997) Vollzugskonzept Siedlungsentwässerung. Bau-, Verkehrs- und Energiedirektion, Bern

Williams H, Jones A (1994) Parasitic worms of fish. Taylor and Francis Ltd, London

Submitted: August 21, 2000; Accepted: January 26, 2001 Proofs received from author(s): March 14, 2001 